\title{
THE ENTREPRENEUR'S STORYTELLING WHO REVIVES FROM FAILURE: A PERSUASIVE ANALYSIS
}

\author{
Lukman Fahmi ${ }^{1}$, Amiatun Nuryana ${ }^{2}$ \\ 1,2Sunan Ampel State Islamic University, Surabaya \\ 1lukman.fahmi@uinsby.ac.id, ²buananuryana@gmail.com
}

\begin{abstract}
This study examines the persuasive techniques used in business storytelling of three entrepreneurs in Surabaya. They are Drs. Daryono, Abdul Chalim, and Samsudin. They experienced a slump in their first business history. Then they becomes a successful entrepreneur in their business until now. This studi applying descriptive qualitative methods. And this study finds that their business storytelling uses some of the seven components of the persuasive technique of Keraf with the use of different types. Drs. Daryono's business storytelling use rationalization, identification, compensation, and projection. Abdul Chalim's business storytelling use rationalization, identification, suggestion, and conformity. And Samsudin's business storytelling use rationalization, identification, suggestion, conformity, compensation, and displacement.The persuasive techniques serve as promotional tools to persuade many schools and institutions persuade many people and make the business grow.
\end{abstract}

Keywords: Business, Entrepreneur, Persuasive Technique, Storytelling.

\begin{abstract}
Abstrak: Penelitian ini membahasa tentang teknik persuasif yang digunakan pada storrytelling bisnis tiga orang penguasaha di Surabaya yang bernama Drs. Daryono, Abd. Chalim, dan Samsudin yang mana mereka pernah mengalami kemerosotan dalam perjalanan bisnis pertamanya. Kemudian mereka bisa sukses di bisnisnya hingga sekarang. Dengan menggunakan metode kualitatif deskriptif, penelitian ini menemukan bahwa storytelling bisnis mereka menggunakan sebagian dari tujuh komponen teknik persuasif dari Keraf yang berbeda-beda. Storytelling bisnis Drs. Daryono menggunakan teknik rasionalisasi, identifikasi, kompensasi, dan proyeksi. Storytelling bisnis Abdul Chalim menggunakan teknik rasionalisasi, identifikasi, sugesti, dan konformitas. Dan storytelling bisnis Samsudin menggunakan teknik rasionalisasi, identifikasi, sugesti, konformitas, kompensasi, dan subtitusi. Teknik persuasive tersebut berfungsi sebagai alat promosi untuk memikat banyak orang dan sangat berguna untuk membuat bisnis tersebut semakin berkembang.
\end{abstract}

Kata kunci: Bisinis, Cerita, Kewirausahaan, Teknik Persuasif.

\section{A. Introduction}

An entrepreneur needs good storytelling in business to promote a business that is being run so that many people are interested in the type of business offered. It is believed to be a powerful tactic to attract consumers in terms of emotional connection or touching the hearts of consumers and maintaining their loyalty to a product or service. Then, storytelling is also considered capable of conveying values in a business. Storytelling techniques in promoting a product or service make consumers more confident about its quality and advantages.

According to Fog et al, storytelling assembled into a story, or narrative structure can function as a communication medium that uses various elements. ${ }^{1}$ So, the use of storytelling in a business has more power or value for promotion. Based on research by Stephens, Silbert, and

\footnotetext{
${ }^{1}$ K. Fog, Budtz, C., \& Yakaboylu, B. Storytelling: Branding in Practice. (Berlin: Springer, 2005).
} 
Hasson, a story told by a speaker is more able to stimulate the hearts of the listeners. When used for business presentations, it can make the audience more excited. ${ }^{2}$ When used for sales, it can make it easier to close. The power of business storytelling in all disciplines, including marketing, has been widely recognized. ${ }^{3}$

Aaker states that a presented story is easier to remember when compared to data and facts. ${ }^{4}$ This method is considered more effective because it can touch the human side of consumers. Besides being easy to remember, stories are also easier to convey messages in a language that is easier for listeners to understand. ${ }^{5}$

Then according to Agustina, to share and convey the values of a product or service, storytelling is considered the best way to be applied. ${ }^{6}$ The use of unique narratives in storytelling is also considered to be more memorable in the hearts of consumers. It can indirectly touch the emotional side of consumers so that they are moved to take action or act to buy a product or service offered. ${ }^{7}$ Storytelling has a vital role in attracting and persuading many people to like the product or service being promoted.

Storytelling in the form of words written on various promotional platforms such as websites, posters, or social media also has an essential role in bringing customers and increasing sales. Therefore, it is highly recommended that the entrepreneurs take the compelling way to promote their products or services by storytelling to influence many people, either directly or indirectly. ${ }^{8}$

Furthermore, to be successful in business requires a strategy because the strategy is a map of the steps to achieve a goal, considering the competition in the business world is quite tight. 9 Therefore, one strategy that can be used to achieve success in business is to use a storytelling strategy. As Rahayu said, storytelling can be a relevant strategy to create emotional relationships with buyers or customers when promoting a product or service.10 An advertisement that uses storytelling with creative narratives becomes more attractive than ordinary ads.

In addition to using strategy, business success can also be achieved by several other factors, such as making the vision and mission of the company's program. The vision here means a goal of the business itself, while the mission is the steps for the business to be successful. Lim said that to achieve spectacular goals in business, one must constantly manage the business like a new business. ${ }^{11}$ Not only that, but also think about its long and short-term targets. Then make daily, monthly, and yearly sales targets. Moreover, often conduct evaluations to monitor the progress that has been implemented to achieve business success.

When everything has been laid out in an orderly manner to achieve business targets and what must be done to achieve these targets has also been made step by step. Then business

${ }^{2}$ G.J. Stephens, Silbert, L.J., \& Hasson, U. "Speaker-Listener Neural Coupling Underlies Successful Communication". Proceedings of the National Academy of Sciences of the United States of America (PNAS). 107, no.32. (2010), 14425-14430.

${ }^{3}$ S. Lowe, Purchase, S., Ellis, N. "The Drama of Interaction within Business Networks". Industrial Marketing Management 41, no. 3 (2012), 421-428.

${ }^{4}$ J.L. Aaker. "Dimensions of brand personality". Journal of Marketing Research (JMR). 34, no.3 (1997), 347356.

${ }^{5}$ A.D. Brown, Gabriel, Y., \& Gherardi, S. "Storytelling and Change: an Unfolding Story". Organization. 16, no.3 (2009), 323-333.

6 T.S. Agustina. "Storrytelling Sebagai Strategi Bisnis Sosial Start-up Ojek Syar'i Berbasis Aplikasi di Surabaya". INOBIS: Jurnal Inovasi Bisnis dan Manajemen Indonesia 03, no.4. (2020), 448-460.

7 W. Lin. \& S. Liou. "How social enterprise attract public awareness using storytelling". Proceedings of the 22nd International Academic Conference. (35505862) (2016), 150-163.

${ }^{8}$ S. Devica "Pengaruh Harga Diskon dan Persepsi Produk Terhadap Nilai Belanja serta Perilaku Pembelian Konsumen”. Jurnal Bisnis Perspektif 7, no.1 (2015), 27-44

9 J. Lim. Strategi Sukses Mengelola Karir dan Bisnis. (Jakarta: Gramedia Pustaka Utama. 2002).

10 W.S.B. Rahayu, W.S.B. "Penggunaan Storrytelling dalam Iklan Line Webtoon pada Sikap Pengguna". Jurnal Ilmiah Mahasiswa Fakultas Ekonomi dan Bisnis Universitas Brawijaya 5, no. 2 (2017), 1-17.

11 J. Lim. Strategi Sukses Mengelola Karir dan Bisnis. 
success will likely be achieved because clear steps that are consistently applied will increasingly bring business development to a successor to a fantastic profit. As Thiel argues, when someone thinks about the future, it is the same as expecting progress in the future. ${ }^{12}$ Therefore, precise planning becomes essential in a business for the future and the progress of the business itself.

An equally vital thing to think about in running a business by an entrepreneur is the company's weakness to be used as evaluation material in patching or covering up these weaknesses to be better than competitors. It can be started by checking all running systemsboth from the promotion, sales, marketing, team performance, and others. As a form of anticipation of failure or bankruptcy in business, because competition in business is indeed relatively challenging for entrepreneurs in terms of prices, discounts, guarantees, and forms of service to consumers.

Therefore, entrepreneurs are encouraged to analyze their business performance, such as what factors can make people buy a lot and what factors can hinder it. Then other supporting tools or instruments are also needed to analyze business management, such as financial statements of profit and loss, payment policies, and sales percentages. ${ }^{13}$ By learning this, entrepreneurs can work on things to do their business better to get optimal income. Lim also stated that Activity Value Analysis (AVA) could improve efficiency and business competitiveness, such as analyzing business work processes. If unfavorable processes are found, they can be immediately changed for the better. ${ }^{14}$

To build, run, and develop a business, an entrepreneur must have an entrepreneurial spirit embedded in him because every entrepreneur must compete to win customers' hearts. 15 Sometimes it is true that the weakness of a novice businessman is only rich in dreams, strong in hope, but weak in execution. Many entrepreneurs also fail because they are not fully mentally prepared to manage their business and do not believe in success. Schwartz also believes that someone will win success when he believes he can succeed because motivation from within must be strong and embedded to be successful. ${ }^{16}$ Then, Henrizal gives entrepreneurship tips, such as an entrepreneur must have a reason why he should do business. Even entrepreneurs must also explore potential and maintain motivation. ${ }^{17}$ Then, he must choose beloved entrepreneurship, make a business development management, go through the process, think about results, and be creative and innovative without limits.

The business history of every entrepreneur is undoubtedly different. Some have been in business for dozens. Even decades have experienced difficulties in improving and getting results from their business. Nevertheless, some achieve success in their business in a relatively short time. Some entrepreneurs go bankrupt because their businesses are no longer able to be maintained. At the same time, several other entrepreneurs can achieve success even though they are swayed by time. Therefore, entrepreneurs are strongly encouraged to think about how the business can develop-starting from thinking about how to market it, promoting it, and attracting many people's hearts. From these cases, persuasion theory can be used as an analytical tool for business history. The most crucial thing about a business is making many people like the product or service of the entrepreneur's type of business. As Muhridha said, persuasive strategies were widely used in various aspects of human life. ${ }^{18}$ In the business field, persuasive strategies are used for marketing or used in other fields. In education, made into a distribution of brochures where

\footnotetext{
12 P. Thiel Zero to One: Notes on Startups, or How to Build the Future. (New York: Crown Business. 2014).

13 J. Lim. Strategi Sukses Mengelola Karir dan Bisnis.

14 Ibid.

15 E.M. Henrizal. Membangun Jiwa Entrepreneur. (Bandung: La Goods Publishing. 2014).

16 D.J. Schwartz. The Magic of Thinking Big. (New York: Fireside. 2007).

17 E.M. Henrizal. Membangun Jiwa Entrepreneur.

18 A. Muhridha. "Strategi Persuasif dalam Brosur Penerimaan Mahasiswa Baru Perguruan Tinggi Swasta Lingkup LLDIKTI IX di Makassar". Thesis. (Universitas Negeri Makassar. 2020). Accessed on June 24, 2021 from http://eprints.unm.ac.id
} 
the use of language in brochures aims to influence many people to use the services or products offered.

Based on the background of the problem, in this article, researchers focus on conducting a study on the two entrepreneurs who built a business, experienced failure, and rebuilt their business to become a success. The first entrepreneur studied in this study is Drs. Daryono. The second entrepreneur is Abd. Chalim. And the third entrepreneur is Samsudin. Drs. Daryono started his business in 1995. His first business was selling books to the schools. The business experienced a stagnation (down) from 1999 to 2002. Then Drs. Daryono returned to the business in 2003 with a new business. The business was booming and much in demand by the schools and still survives today. Same as Abd. Chalim also started his business in 1995, then he experienced a stagnation in 1998. He rebuilt his business in 2001 until he achieved his success so far. Then, not much different from Samsudin who has also been in the business of selling books since 1997 with all the bittersweet stories until he achieved his success in selling books. Therefore, the researchers are interested in carrying out a study that focuses on the formulation of the problem: How is Drs. Daryono, Abd. Chalim, and Samsudin started from the first time in business until now. Then how Drs. Daryono, Abd. Chalim, and Samsudin uses persuasive techniques in storytelling in his business to become successful.

\section{B. Literature Review}

\section{Entrepreneur's Storytelling and Persuasive Techniques}

Practically, storytelling can strengthen the products or services offered by entrepreneurs and persuade many people to be interested in buying and using the products or services. According to Ballester \& Sabiote, many entrepreneurs use a storytelling strategy to develop and promote their businesses. ${ }^{19}$ Robin mentions that there are seven elements in storytelling, namely point of view, dramatic question, emotional content, processing the story, the power of the soundtrack, a story that enough to make the audience understand, and pacing. ${ }^{20}$ Meanwhile, according to Fog, et.al., storytelling has four components in its delivery such as message, the story's ability to convey messages, a person's ability to convey the story, and the plot from the opening to the end.21

Storytelling can be used as a promotional tool because it can elevate business value and add a sense of quality to the products or services. Not only that, it can convey what and how the product or service is and distinguish its quality from its competitors. Consumers usually tend to look for stories and explanations that touch their hearts to make them believe in buying and using a product or service. Because good storytelling will eventually make consumers give an upbeat assessment of the product or service used.

Besides using storytelling for promotion, it also requires persuasive techniques so that storytelling can be conveyed effectively. The persuasive technique is a way that makes promotional language can stimulate someone's feelings and hearts to do something. ${ }^{22}$ So storytelling and persuasive techniques are closely related to making successful marketing of a product or service.

Then, to make storytelling into persuasive writing or sentence, several techniques can achieve the desired goal. The persuasive techniques are as follows: 1) Rationalization, which is a process to use reason to provide fundamental justification for a problem. 2) Identification, the speaker or writer must first analyze who the audience or reader is and what the situation is at that time to present appropriate information for public consumption. 3) Suggestion, an attempt

\footnotetext{
${ }^{19}$ E.D. Ballester \& E.F. Sabiote. "Oce upon a brand: Storytelling practices by Spanish brands". Spanish Journal of Marketing (ESIC) 20(2016), 115-131

${ }^{20}$ B.R. Robin. "Digital Storytelling: A powerful technology tool for the 21st-century classroom". Theory Into Practice. 47, no.3. (2008), 220-228.

${ }^{21}$ K. Fog, Budtz, C., \& Yakaboylu, B. Storytelling: Branding in Practice.

22 G. Keraf. Argumentasi dan Narasi. Jakarta: Gramedia Pustaka Utama. 2007.
} 
to influence or persuade many people to believe in a series of words conveyed. 4) Conformity, an act to be similar to something else and a mental mechanism to conform to something desired, such as an attitude of the writer or speaker trying to adjust to the situation not to seem tense. 5) Compensation results from finding a substitute for something unacceptable or an attitude and response to an untenable situation. 6) Displacement, an effort to replace hateful emotions and replace things that experience an obstacle, so the speaker or writer tries to package the best words from foul language. 7) Projection, a technique to change what was previously a subject into an object.

When concluded, persuasion techniques aim to invite readers or many people, present facts, opinions, and ideas. It also aims to convince many people with language or words on target like the various persuasive techniques above. So, the words or sentences in storytelling can be arranged based on persuasive techniques to convince consumers and make them move to buy or use the product or service being promoted.

Several previous researchers have researched business storytelling and persuasive techniques. Among them, such as a study conducted by Nugroho with the title "Analisis Variasi Kalimat dan Penggunaan Teknik Persuasif dalam Spanduk Kampanye Calon Presiden dan Wakil presiden Republik Indonesia Tahun 2014 di Kota Yogyakarta" ("Analysis of Sentence Variations and the Use of Persuasive Techniques in Campaign Banners for the 2014 Presidential and VicePresidential Candidates of the Republic of Indonesia in the Yogyakarta City"). ${ }^{23}$ This study shows variations in sentences in news sentences, exclamation sentences, and imperative sentences. The persuasive techniques found in this study used on campaign banners are rationalization, identification, suggestion, conformity, compensation, substitution, and projection techniques.

Furthermore, a study conducted by Muhridha entitled "Strategi Persuasif dalam Brosur Penerimaan Mahasiswa Baru Perguruan Tinggi Swasta Lingkup LLDIKTI IX di Makassar" ("Persuasive Strategy in the New Student Admission Brochure for Private Higher Education Scope of LLDIKTI IX in Makassar"). ${ }^{24}$ In her research only three persuasive techniques were found used in the new student admission brochure. The types of persuasive techniques found in this research are rationalization, suggestion, and identification techniques. The element of rationalization technique in the form of words of argument and facts will be helpful to the reader. Then, the element of the suggestive technique is in the form of a quote accompanied by a basis. Furthermore, the element of identification technique in the form of a college motto is listed in the brochure.

As for other research researched by Anita \& Lestari with the title "Konsep Brand Storytelling, Value Perceptions dan Visit Intention Pada Kawasan Tujuan Wisata di Jakarta (Survey pada Video Iklan Taman Mini Indonesia Indah di Youtube)" ("The Concept of Brand Storytelling, Value Perceptions and Visit Intentions in Tourist Destinations in Jakarta (Survey on the Video Advertising of Taman Mini Indonesia Indah on Youtube)"). ${ }^{25}$ It examines how the influence of brand storytelling on value perceptions and how they impact visit intention. In this study, the analytical technique did not use a persuasive technique but a path analysis technique. It was resulting in findings that brand storytelling has a very significant influence on value perceptions.

Then examine the research conducted by Pravitaswari, Arifin, \& Mawardi conducted on 100 active netizens or consumers who have purchased Allure Matcha Latte products. ${ }^{26}$ The title of this

\footnotetext{
${ }^{23}$ A. Nugroho, A. "Analisis Variasi Kalimat dan Penggunaan Teknik Persuasif dalam Spanduk Kampanye Calon Presiden dan Wakil Presiden Republik Indonesia Tahun 2014 di Kota Yogyakarta". Thesis. (Universitas Negeri Yogyakarta. 2015). Accessed on June 24, 2021 from https://eprints.uny.ac.id

${ }^{24}$ A. Muhridha. "Strategi Persuasif dalam Brosur Penerimaan Mahasiswa Baru Perguruan Tinggi Swasta Lingkup LLDIKTI IX di Makassar".

${ }^{25}$ T.L. Anita, T.L. \& N.S. Lestari. "Konsep Brand Storrytelling, Value Perceptions Dan Visit Intention pada Kawasan Tujuan Wisata di Jakarta (survey pada video iklan Taman Mini Indonesia di YouTube)". Jurnal IPTA (Industri Perjalanan Wisata) 8, no.2, (2020).pp. 281-291

${ }^{26}$ N. Pravitaswari., Z. Arifin, \&, M.K. Mawardi. "Pengaruh Storrytelling Marketing terhadap Brand Equity dan Keputusan Pembelian (Survei Pada Video Iklan Allure Matcha Latte Story Di Youtube)". Jurnal Administrasi Bisnis (JAB). 57, no.1, (2018).pp.30-37.
} 
research is "Pengaruh Storytelling Marketing Terhadap Brand Equity dan Keputusan Pembelian (Survei Pada Video Iklan Allure Matcha Latte Storry di Youtube)" ("The Effect of Storytelling Marketing on Brand Equity and Purchase Decision (Survey on Allure Matcha Latte Story Advertising Video on Youtube)"). This study indicates that storytelling marketing influences brand equity. Even it impacts consumer purchasing decisions and states that storytelling marketing is an effective strategy to make consumers buy a product.

A study conducted by Agustina with the title "Storrytelling Sebagai Strategi Bisnis Sosial Start-Up Ojek Syar'i Berbasis Aplikasi di Surabaya" ("Storytelling as a Social Business Strategy for Start-Up Ojek Syar'i Application-Based in Surabaya"). ${ }^{27}$ It shows that storytelling in social business is the best way to convey the social values of the business. The researcher concludes that storytelling is a suitable medium to expand the wings of the Ojek Syar'i social business. The storytelling strategies used by the Ojek Syar'i business are data-driven storytelling, philanthropic storytelling, customer-led storytelling, and commercial storytelling.

Next, looking at the research conducted by Rahayu with the big topic "Penggunaan Storytelling dalam Iklan Line Webtoon Pada Sikap Pengguna" ("The use of Storytelling in Line Webtoon Ads on User Attitudes").28 It provides findings or research results that using storytelling in Line Webtoon advertisements has influenced user attitudes. The storytelling is relevant to users who are primarily teenagers to create an emotional bond successfully. Besides that, it can also make users remember to use Line Webtoon more often.

Furthermore, a study researched by Silangit \& Haryanto entitled "Penggunaan Storytelling untuk Meningkatkan Kesiapan untuk Berubah Pada Karyawan" ("The use of Storytelling to Increase Readiness to Change in Employees") explores the use of storytelling in conveying the five components of a change message to employees. ${ }^{29}$ The data in this study were analyzed using the Wilcoxon Signed-Rank Test. The researcher concludes that the results of this study indicate that storytelling is an effective strategy to improve the quality of employee readiness to change.

Various kinds of previous research related to storytelling and persuasive techniques found several gaps to provide a position for this latest research to be carried out. Storytelling is essential in promoting a business, and persuasive techniques also have a crucial role in developing a better business and maintaining its existence among many competitors.

\section{Methodology}

This study applies descriptive qualitative methods in researching an entrepreneur's storytelling which helps analyze, classify, describing, and validating the findings of persuasive techniques on Drs. Daryono, Abdul Chalim, and Samsudin's business storytelling. The data in this study are in the form of words or sentences by the research topic collected through observation and interview techniques.

The data source in this study was Drs. Daryono, Abdul Chalim, and Samsudin, three entrepreneurs who have 24 and 26 years of experience in running a business built by themself. Moreover, the data analysis in this study used descriptive qualitative analysis by applying persuasive techniques to the business storytelling of Drs. Daryono, Abdul Chalim, and Samsudin, which will be presented in an arrangement of paragraphs.

\footnotetext{
27 T.S. Agustina. “Storrytelling Sebagai Strategi Bisnis Sosial Start-up Ojek Syar'i Berbasis Aplikasi di Surabaya".

28 W.S.B. Rahayu, W.S.B. "Penggunaan Storrytelling dalam Iklan Line Webtoon pada Sikap Pengguna”.

${ }^{29}$ E.V.B. Silangit \& F.R. Haryanto. "Penggunaan Storrytelling untuk Meningkatkan Kesiapan untuk Berubah pada Karyawan". Jurnal Intervensi Psikologi 6, no.2, (2014), 193-212.
} 


\section{Findings and Discussion \\ 1. The Entrepreneur's Business History}

The first finding in this study is related to the business history of Drs. Daryono, Abdul Chalim, and Samsudin covers their first business. The factors that caused the decline of their first business and the factors that made them return to business until succeed.

\section{a. Drs. Daryono's Business History}

Drs. Daryono is a businessman who lives in Surabaya. He was born in Kediri on March 15, 1966. He is 55 years old and still pursuing his current business. He is a graduate of English education at STKIP Kediri. Furthermore, he already has 26 years of experience in the business field. Drs. Daryono's first business was selling books to schools around Surabaya, Sidoarjo, Gresik, and Mojokerto from 1995 to 1998. He did the book-selling business alone without involving employees and using private transportation. Then from 1999 to 2002, the business experienced a downturn because the profit earned with the capital issued was not balanced. It is because book buyers or enthusiasts tend to be quiet so that their turnover decreases.

So the initial turnover was permanently reduced so that it had an impact on the income of Drs. Daryono. Book orders from schools received by Drs. Daryono is not much anymore. The decrease in turnover is experienced every turn of the year until finally Drs. Daryono decided not to sell books anymore and stopped selling books.

Drs. Daryono is a patient businessman, not an ambitious figure. So that when he finds his business slumping, his mentality is accepting, not blaming the situation. Moreover, he is also a person who is not easily discouraged. So when he experienced a slump in his book-selling business, he also thought of breakthroughs to improve his business. He is also a businessman who is seen from the side of his religion quite well. It is evidenced by several of his posts on social media that discuss the values of religious teachings. Therefore it is no longer surprising that Drs. Daryono is known as a patient and trusting figure. In addition to the pure motivation that comes from oneself, his wife, children, and siblings, also become the reinforcing figures and always motivate Drs. Daryono in the face of a downturn in his business. So he did not stop trying and tried to think about his future to support his family.

In 2003, Drs. Daryono has rebuilt a new business that focuses on the service sector by establishing a Basic English Training Surabaya, abbreviated as BETS. The reason Drs. Daryono decided to establish BETS, apart from being motivated to fulfill the necessities of life, Drs. Daryono also has the intention to develop his knowledge in the field of English to be useful for many people.

While the reason Drs. Daryono did not return to the book-selling business because he thought that the literacy rate in Indonesia was still low. Then there were also many competitors, and the current era of globalization requires a generation who can speak English. The connection between the first business and the current one is that both have education and efforts to educate the nation's children.

The BETS institution was promoted to schools around Surabaya, Sidoarjo, Gresik, and Mojokerto. It provides English language courses in TOEFL, TOEIC, and conversation using a collaborative proposal. He also develops the business by making or printing his books about learning English which he sells to students gathered in his course institution. The course business called BETS was successfully managed and is still running today. Even BETS has teaching staff recruited by Drs. Daryono to teach or fill English courses in schools. The current number of BETS teachers is around fifty tutors who have English language competence.

His close friends also support and help Drs. Daryono in managing BETS. So when BETS was founded, Drs. Daryono recruited his close friends who have English language skills to become teachers who provide courses in schools. Furthermore, the knowledge of English that he learned in college was also a factor that inspired Drs. Daryono to spread his knowledge. Therefore, the current existence of BETS which Drs. Daryono founded has become a field for developing English knowledge, which is in demand by many schools and students. The schools that BETS successfully provided courses include: SMA Negeri 2 Sidoarjo, SMA 3 Sidoarjo, SMA Negeri 1 Taman Sidoarjo, 
SMA 16 Surabaya, SMA GIKI 2 Gubeng Surabaya, SMA Negeri 1 Manyar Gresik, SMA Negeri 1 Cerme Gresik, SMP Negeri 1 Duduksampeyan Gresik, Nursing Academy Dian Husada Mojokerto, and many more.

BETS course at the school is held once a week. The types of BETS courses include English for Teacher, English for Nurse, English Conversation, and TOEFL. The existence of BETS makes Drs. Daryono is grateful that the business that was founded in 2003 is still surviving today. As for the business profit of the English course, if it is presented as a percentage, $60 \%$ is for Drs. Daryono and $40 \%$ for schools that are given courses. However, $60 \%$ of the profit earned by Drs. Daryono is still used to pay and print English learning books. With such a profit, for Drs. Daryono has made him feel enough and grateful. Because back to the original intention, that the purpose of his business and the necessities of life, Drs. Daryono has a great intention to take advantage of his knowledge of the English language.

\section{b. Abd. Chalim's Business History}

Abd. Chalim is an entrepreneur who lives in Surabaya. He was born in Surabaya, August 7, 1967. So, he is 54 years old now. He graduated in communication science at the Universitas Dr. Soetomo Surabaya. It's the same with Drs. Daryono, Abd. Chalim has 26 years of experience in the business.

Abd. Chalim's first business is selling books by setting up book stands at Pasar Turi, Blauran, and Jalan Semarang. He started his business in 1995. He marketed the book on the roadside around Surabaya. And went bankrupt in 1998 along with the monetary crisis that year. For three years he was vacuum in the business.

Then in $2001 \mathrm{Abd}$. Chalim began to rise and do business again with the same business as his first business. This is due to the passion and hobby of Abd. Chalim who likes to read books. In addition, family factors are also the main motivation in doing business. Now his business has grown and achieved success because of Abd. Chalim cooperates with schools and universities. The books offered to many lecturers are in accordance with the majors taught by the lecturer. Books that have many series are sold on an installment basis so that buyers don't feel burdened by having to pay all at once in a fairly expensive amount.

Schools that asked Abd. Chalim for a supply of books is SD Al-Falah Assalam Tropodo Sidoarjo, SMP Al-Falah Assalam Tropodo Sidoarjo, SMA Widya Dharma Surabaya, and SMA Raden Patah Mojosari Mojokerto.

\section{c. Samsudin's Business History}

Furthermore, the third entrepreneur is Samsudin who has also been in the business of selling books since 2005 at UIN Sunan Ampel Surabaya. He is from Yogyakarta, born on 27 September 1977. He is now 44 years old. So, until now he already has 24 years of business experience. In 1997 to 2000, his book selling business was selling well because at that time it coincided with the reformation of reading interest when he was still selling at UI (University of Indonesia).

Meanwhile, when selling at UIN Sunan Ampel Surabaya, most of the profit earned was around 2007-2009, because most students looked for reference books in the library and bookstores at UIN Sunan Ampel Surabaya. In addition, in 2006 at that time there was also the Surabaya Reading Community, where after the study, its members were required to read books.

Samsudin experienced a decline in its business around 2016-2017. This is because the bookstore at UIN Sunan Ampel Surabaya is located in a narrow place and quite far from the reach of students. And since 2018 he has collaborated with campuses or is involved in contracts to sell books at the UINSA Book Store. Then since the pandemic period in 2020 Samsudin has achieved success by supplying books to schools. The schools that asked Samsudin to supply books include SD Al-Falah Darussalam Sidoarjo, SMP Al-Falah Darussalam Sidoarjo, SMK Ketintang Surabaya, and SMA Angkasa Mojokerto. 
In addition, he is also actively selling books through the online system as a book reseller. However, he also feels the intricacies of selling online, because the competition is quite difficult. In addition, nowadays we are also competing with technological advances, where there are already many books in PDF format or e-books that can be accessed directly by many people.

\section{The Use of Persuasive Techniques of the Entrepreneur's Business Storytelling}

The second finding of the discussion is about the use of persuasive techniques of the Drs. Daryono, Abdul Chalim, and Samsudin's business storrytelling.

\section{a. Drs. Daryono's Business Storytelling}

The subsequent discussion is about the results of the analysis of persuasive techniques on the storytelling of business proposals and other documents submitted by Drs. Daryono to schools and institutions. Of the seven components of persuasive techniques, based on the analysis results in this study, it was found that the business storytelling of Drs. Daryono uses persuasive techniques of rationalization, identification, compensation, and projection. A more detailed discussion is as follows below.

\section{1) Rationalization}

Indicators of justification for a problem characterize persuasive rationalization techniques. It is not an absolute truth, only justifying their thoughts, controlling emotions, and involving ratios or thoughts. ${ }^{30}$ The discussion of rationalization techniques in this study is as follows.

"Begitu pentingnya peranan bahasa Inggris dalam berbagai bidang di era globalisasi sekarang ini, bahkan bahasa Inggris bisa menjadi penentu masa depan".

("The role of English is vital in various fields in today's era of globalization, even English can be a determinant of the future").

The sentence invites the reader to think until finally determining the truth and agreeing with the opinion in the proposal sentence. The sentence above states that English has an essential role in globalization and can even be a determinant of one's future. It is a logical thought in promoting English courses that people who study English will have a future. English has a vital role in various fields in the current era of globalization.

\section{2) Identification}

Persuasive identification technique is a technique that has the characteristics of highlighting identity. It also mentions the name or identity of an object, institution, or person, ${ }^{31}$ as stated in the storytelling business proposal in this study.

"Kami (Basic English Training Surabaya) menawarkan kerjasama menyelenggarakan program ekstrakurikuler bahasa Inggris seperti TOEFL, TOEIC, dan Conversation atau program lain yang mendukungnya".

("We (Basic English Training Surabaya) offer cooperation in organizing English extracurricular programs such as TOEFL, TOEIC, and Conversation or other programs that support it").

In the sentence "TOEFL, TOEIC, dan Conversation atau program lain yang mendukungnya," BETS (Basic English Training Surabaya) course institution intends to identify the course institution. The sentence means that BETS has English course services in the fields of TOEFL, TOEIC, and Conversation or other programs that support it. Then, the word "atau program lain

\footnotetext{
30 G. Keraf. Argumentasi dan Narasi.

31 Ibid.
} 
yang mendukungnya" means that it can be in the form of other English courses. It is according to the needs of the institution or school that can be delivered to BETS.

\section{3) Compensation}

Storytelling in the BETS agency's business proposal attempts to promote its English language course program to be in demand or accepted by schools and institutions. In the proposal found a persuasive compensation technique was used to attract the attention of the reader. Compensation techniques are characterized by having an action or result of an effort, intending to realize a goal, and inviting to create better conditions, ${ }^{32}$ as stated in the business proposal of Drs. Daryono below.

"Adapun Visi kami adalah:

1. Mengasah keterampilan kognitif, afektif, dan psikomotorik yang terdapat pada siswa sesuai tingkat kemampuannya dan mengembangkannya.

Misi:

1. Membudayakan komunikasi bahasa asing di sekolah

2. Memberikan bekal keterampilan berbahasa asing pada siswa sekolah

3. Meningkatkan keterampilan dan pengalaman pembelajaran yang berbeda

4. Membentuk mindset yang kreatif dan inovatif untuk kemajuan pribadi siswa"

("Our vision is:

1. Sharpen the cognitive, affective, and psychomotor skills found in students according to their ability level and develop them.

Missions:

1. Cultivate foreign language communication at school

2. Providing foreign language skills for school students

3. Enhance different skills and learning experiences

4. Forming a creative and innovative mindset for the personal progress of students")

The sentences above mention the vision and mission of the BETS course institution. Based on the researcher's analysis, the vision and mission of BETS use persuasive compensation techniques because it has one of the indicators of compensation technique's characteristics, namely to realize a goal. As in the vision sentence above it can be interpreted that if BETS institutions are accepted to provide courses in schools. The compensation that schools will obtain is students whose cognitive, affective, and psychomotor skills are honed according to their ability level. BETS will also develop students' skills.

Likewise, in BETS mission sentences to realize its vision or goals, the mission sentences have the characteristics of compensation technique indicators. Namely, realize the vision goals and invite schools to create better conditions in English with these four missions. The four mission sentences mean that the BETS institution will provide compensation if accepted to provide courses in schools by cultivating communication in foreign languages for students. It is also providing foreign language skills, improving skills and different learning experiences, and forms a creative and innovative mindset for the personal progress of students. So, that is all the compensation that schools and students will get if they choose BETS to provide courses. All these compensations will certainly attract schools and other institutions to believe in BETS in providing courses because BETS already has a clear and structured vision and mission.

4) Projection

\footnotetext{
32 Ibid. 
The projection technique is also used in promoting BETS. This technique is characterized by indicators such as making the subject into an object and describing a good thing related to something or someone. ${ }^{33}$ As the projection sentence on BETS business storytelling managed by Drs. Daryono follows.

"Sehubungan dengan hal tersebut kami mohon agar anak didik BETS untuk berpartisipasi dan mempersiapkan lomba dengan sebaik mungkin. Adapun pemenang lomba English Talent 2018 akan mendapatkan sertifikat dan thropy. Sedangkan semua peserta yang mengikuti English Talent 2018 berhak mendapatkan sertifikat."

("In connection with this, we request that BETS students participate and prepare for the competition as well as possible. The winners of the 2018 English Talent competition will get a certificate and a trophy. Meanwhile, all participants who take part in English Talent 2018 are entitled to a certificate.")

In the sentence above, the projection technique used aims to project certificates and trophies for participants and winners when participating in the English Talent competition. It is intended to give a good image or impression of the English Talent competition organized by BETS. The English Talent is a competitive program that is promoted so that BETS students can participate. The sentence "kami mohon agar anak didik BETS untuk berpartisipasi dan mempersiapkan lomba dengan sebaik mungkin" is an invitation, recommendation, or order for BETS students to take part in the English Talent competition. The existence of trophies and certificates gives a good image that BETS appreciates all of its students who have been willing to process and try to compete in English Talent.

\section{b. Abdul Chalim's Business Storytelling}

Based on the data of Abdul Chalim's media for promoting his book business, he use a uniqe business storytelling to persuade many people to buy his book collections. The researchers found seventeen data that use persuasive techniques. And the type of persuasive techniques from seventeen data, they use rationalization, identification, suggestion, and conformity. The detail explanation are follow.

1) Rationalization

The researchers only found one rationalization type of the seventeen persuasive techniques in Abdul Chalim's business storytelling as follow.

"Sesungguhnya semakin kita belajar maka semakin bertambah pengetahuan dan wawasan kita, serta semakin bijaklah kita maka semakin cepat sukseslah kita."

("In fact, the more we learn, the more knowledge and insight we have, and the wiser we are, the faster we will succeed.")

The sentence above aims to provide an opinion regarding someone if they always study, their knowlegde will increase and when someone is wiser, they will quickly bocome succesful. The opinion involves a ration to justify the opinion even though it is not an absolute truth. With this rationalization technique in Abdul Chalim's business storytelling, he tries to lead readers to like reading and learning by increasing their knowledge so that he is also interested in buying books uploaded by Abdul Chalim on his social media with these sentences.

2) Identification

Same as rationalization type, in Abdul Chalim's business storytelling the researchers only found one identification type of seventeen persuasive techniques that use by him as follow.

"Tafisr Maudui, Tafsir Tematik"

33 Ibid. 
The words above indicate for promoting the thematic interpretation book type that uploaded by Abdul Chalim in his social media by mentioning the name of the books "Tafsir Maudui". So, public will know clearly that book sold by Abdul Chalim is about thematic interpretation. Because one of the character of identification is mention directly the name of something to identify itself.

\section{3) Suggestion}

In Abdul Chalim's business storytelling, the researcher found eleven suggestion type of seventeen persuasive techniques that use by Abdul Chalim for promoting his book business. One of them is as follow.

\section{"Hujan hujan jangan lupa ngopi dulu, yo ngopi, yo moco mukjizat kemukjizatan" \\ ("It's raining, don't forget to drink coffee first, coffee yes, read miracles yes".)}

From the sentence above, Abdul Chalim tries to persuade many people to keep reading books even when it's raining accompanied by coffee. This aside from being an invitation or suggestion, Abdul Chalim actually also meant for people to buy his collection books about miracles whose pictures were uploaded on his social media with storytelling containing the suggestion's persuasion technique.

\section{4) Conformity}

From the seventeen persuasive techniques that used in Abdul Chalim's business storytelling, the researcher found four conformity type of persuasive technique. One of them is as follow.

\section{"Suasana ladang sawah yang menyejukkan, nikmat dengan dibarengi bacaan yang menyenangkan. Baca, Baca, dan Baca!"}

("The atmosphere of the rice fields is soothing, delicious accompanied by pleasent reading. Read, read, and read!")

The sentences above have an attempt to match that in therice fields it is suitable for reading books. The word fun reading actually has the intention of making people read the type of book whose pictures have been uploaded by Abdul Chalim on his social media. So, rice fields can be one of the choices of a comfortable place to read a book. Especially reading the book promoted by Abdul Chalim.

\section{c. Samsudin's Business Storytelling}

Based on the data of Samsudin's business storytelling, the researchers found twenty five of persuasive techniques that used for promoting his books collection. The type of persuasive technique used by Samsudin are rationalization, identification, suggestion, conformity, and displacement. The detail explanation of the analysis are as follow.

\section{1) Rationalization}

There are four rationalization type of persuasive techniques from twenty five data that found in Samsudin's business storytelling. One of them is as follow.

"Ada beberapa tindakan yang lebih jahat ketimbang membakar buku. Salah satunya adalah tidak membacanya. -Joseph Brodsky"

("There are few acts that are worse than committing to a book. One of them is not reading it.")

The sentences above is the writing on the banner in front of Samsudin's bookstore. They are storytelling of his business using the persuasive rationalization technique. The characteristic of 
rationalization in the sentence is an opinion that provide justification for a problem. As Samsudin agrees with Joseph Brodsky's words, and Joseph Brodsky himself makes the word involve the ratio that according to him one of the evil acts includes not reading book. For Samsudin, the statements can be used as a way of promotion so that students come to buy a book.

2) Identification

Based on the analysis of all data, the researcher found seven persuasive identification techniques used in Samsudin business storytelling to sell his books. One of them is as follows.

"Buku terbaru karya Pak Masdar Hilmy. Tersedia di toko buku Sunan Ampel Surabaya. Monggo engkang berminat!"

("The latest book by Mr. Masdar Hilmy. Available at Sunan Ampel Surabaya bookstore. Please those who are interested!")

The sentence above is included in the category of persuasive identification techniques, because the word "latest" indicates that Mr. Masdar Hilmy has a recently published book. Plus the information that the book is only available at the Sunan Ampel Surabaya bookstore, which means it's not available anywhere else. All of this is information for the people who defined Pak Masdar Hilmy's latest book.

3) Suggestion

The suggestion techniques found in Samsudin business storytelling are ten of the existing data, one of which is as follows below.

"Cepet-cepet mumpung lagi diobral"

("Hurry up while it's on sale")

The words above have the intention of spurring many people, especially students in the campus environment, to immediately come to buy the books offered by Samsudin. Because the book is on sale, of course, at a lower price than the original price. Therefore, Samsudin suggested with the word persuasion to buy quickly so as not to be in a hurry because it had been bought and hunted by other people.

4) Conformity

In Samsudin's business storytelling, only one type of conformity technique was found out of twenty-five persuasion techniques used by Samsudin in promoting his book as follows.

"Seperti halnya gelombang lautan ada pasang surut dan pasang naik, begitu pula dodolan buku."

("Just as ocean waves have ups and downs, so does book sales")

Samsudin's storytelling above is characterized by a conformity persuasive technique. It can be seen from the parable of the condition of the ocean tides and their daily selling of books which also experiences ups and downs. Samsudin felt the ups and downs in selling books from the number of people who bought them and the income they got from selling books. This sentence also serves to try to persuade many people to come to buy from the many collections of Samsudin's books that have piled up in bookstores.

5) Compensation

Two compensation techniques were found in Samsudin business storytelling on his social media. One of them is as follows. 
"RUTH T. MCVEY. Kemunculan Komunisme Indonesia. 198.000 jadi 120.000. Masih dapet bonus 2 buku. Sejarah kecil Indonesia-Perancis 1800-2000. Tulisan Jean Rocher dan Iwan Santosa."

("RUTH T. MCVEY. Kemunculan Komunis Indonesia. 198,000 to 120,000. Still got 2 bonus books. A small history of Indonesia-France 1800-2000. Written by Jean Rocher and Iwan Santosa.")

From the sentences above, Samsudin's storytelling shows that there is compensation for people who buy a book entitled Kemunculan Komunisme Indonesia by RUTH T. MCVEY in the form of a discount of 78,000 from the original price. Then added with the bonus of two books with the theme of Indonesia as well. The compensation technique used by Samsudin in promoting his books is very useful in attracting many people to take this opportunity. Because buy one free open two books.

\section{6) Displacement}

In Samsudin's business storytelling, researchers only found one type of displacement out of twenty-five persuasive techniques used in the promotion of books sold by Samsudin, as below.

\section{“Kemana si kutu buku?"}

\section{("Where's the nerd?")}

The words mentioned above are a persuasive technique of displacement or substitution which actually has the intention of asking book buyers or people who like to read books to come and buy the books sold by Samsudin. The word "nerd" is a proverb of people who like to read books. The word was used by Samsudin is divert public attention to a certain goal.

\section{The Comparison of Drs. Daryono, Abdul Chalim, and Samsudin's Business Storytelling}

Based on the findings from business storytelling used by Drs. Daryono, Abdul Chalim, and Samsudin there are differences in the persuasive techniques used. The difference can be seen in Figure 1 below.

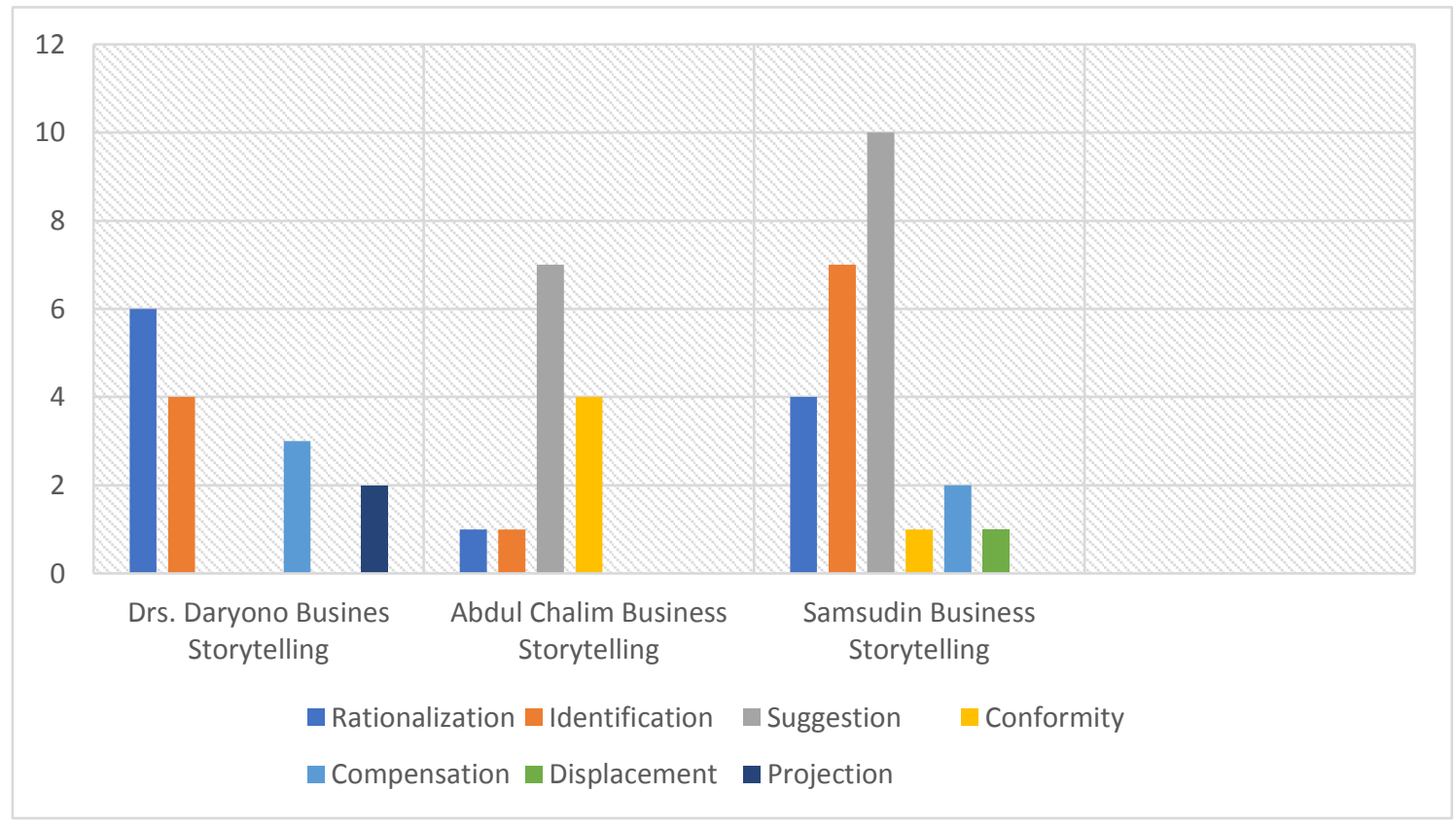


Figure 1: The Entrepreneurs' Comparison Business Storytelling

From the graphic above, it can be clearly seen that in business storytelling of Drs. Daryono is more dominant in using rationalization techniques in promoting his course institution (BETS). Then Abdul Chalim and Samsudin were more dominant in using suggestion techniques in promoting their book selling business. Moreover, they are in line with what Keraf said that persuasive techniques in business could attract consumers' hearts. ${ }^{34}$ Then, all the type of persuasive techniques used in line with Wijayanti that persuasive techniques are applied to persuade people to promote a business. ${ }^{35}$

\section{E. Conclusion}

Based on the analysis of the findings and discussions described above, the seven types of persuasive techniques used in business storytelling of Drs. Daryono can be concluded has four persuasive techniques, namely rationalization, identification, compensation, and projection without suggestion, conformity, and displacement techniques. Abdul Chalim business storytelling also has four persuasive techniques, they are rationalization, identification, suggestion, and conformity without compensation, displacement, and projection techniques. While Samsudin use six of persuasive techniques include rationalization, identification, suggestion, conformity, compensation, and displacement without projection technique. The persuasive techniques they use have an effect in persuading customers to come to them.

\section{References}

Aaker, J.L. "Dimensions of brand personality". Journal of Marketing Research (JMR). 34 (3) (1997), 347-356.

Agustina, T.S. “Storrytelling Sebagai Strategi Bisnis Sosial Start-up Ojek Syar'i Berbasis Aplikasi di Surabaya". INOBIS: Jurnal Inovasi Bisnis dan Manajemen Indonesia 03, no.04 (2020), 448460.

Anita, T.L. \& Lestari, N.S. “Konsep Brand Storrytelling, Value Perceptions Dan Visit Intention pada Kawasan Tujuan Wisata di Jakarta (survey pada video iklan Taman Mini Indonesia di YouTube)". Jurnal IPTA (Industri Perjalanan Wisata) 8, no.2, (2020), 281-291.

Ballester, E.D. \& Sabiote, E.F. "Oce upon a brand: Storytelling practices by Spanish brands". Spanish Journal of Marketing (ESIC) 20(2016), 115-131

Brown, A.D., Gabriel, Y., \& Gherardi, S. "Storytelling and Change: an Unfolding Story”. Organization. 16, no.3, (2009), 323-333.

Devica, S. "Pengaruh Harga Diskon dan Persepsi Produk Terhadap Nilai Belanja serta Perilaku Pembelian Konsumen". Jurnal Bisnis Perspektif 7, no.1 (2015), 27-44.

Fog, K., Budtz, C., \& Yakaboylu, B. Storytelling: Branding in Practice. Berlin: Springer. 2005.

Henrizal, E.M. Membangun Jiwa Entrepreneur. Bandung: La Goods Publishing. 2014.

Keraf, G. Argumentasi dan Narasi. Jakarta: Gramedia Pustaka Utama. 2007.

Lim, J. Strategi Sukses Mengelola Karir dan Bisnis. Jakarta: Gramedia Pustaka Utama. 2002.

\footnotetext{
34 Ibid.

35 T.P. Wijayanti.T.P. “The Style of Persuasive in Home Shopping Network (HSN) of the United States”. Thesis.

(UIN Sunan Ampel Surabaya, 2020) Accessed on June 21, 2021 from http://digilib.uinsby.ac.id/
} 
Lin, W. \& Liou, S. "How social enterprise attract public awareness using storytelling". Proceedings of the 22nd International Academic Conference. (35505862) (2016), 150-163.

Lowe, S., Purchase, S., Ellis, N. "The Drama of Interaction within Business Networks". Industrial Marketing Management 41, no.3 (2012), 421-428.

Muhridha, A. Strategi Persuasif dalam Brosur Penerimaan Mahasiswa Baru Perguruan Tinggi Swasta Lingkup LLDIKTI IX di Makassar. Thesis. Universitas Negeri Makassar. 2020. Accessed on June 24, 2021 from http://eprints.unm.ac.id

Nugroho, A. "Analisis Variasi Kalimat dan Penggunaan Teknik Persuasif dalam Spanduk Kampanye Calon Presiden dan Wakil Presiden Republik Indonesia Tahun 2014 di Kota Yogyakarta”. Thesis. Universitas Negeri Yogyakarta. 2015. Accessed on June 24, 2021 from https://eprints.uny.ac.id

Pravitaswari, N., Arifin, Z., \& Mawardi, M.K. "Pengaruh Storrytelling Marketing terhadap Brand Equity dan Keputusan Pembelian (Survei Pada Video Iklan Allure Matcha Latte Story Di Youtube)". Jurnal Administrasi Bisnis (JAB). 57, no.1, (2018),.pp.30-37.

Rahayu, W.S.B. "Penggunaan Storrytelling dalam Iklan Line Webtoon pada Sikap Pengguna". Jurnal Ilmiah Mahasiswa Fakultas Ekonomi dan Bisnis Universitas Brawijaya. 5 (2) (2017), 117.

Robin, B.R. "Digital Storytelling: A powerful technology tool for the 21st-century classroom". Theory Into Practice. 47, no.3. (2008), 220-228.

Schwartz, D.J. The Magic of Thinking Big. New York: Fireside. 2007.

Silangit, E.V.B. \& Haryanto, F.R. "Penggunaan Storrytelling untuk Meningkatkan Kesiapan untuk Berubah pada Karyawan”. Jurnal Intervensi Psikologi 6, no.2, (2014), 193-212.

Stephens, G.J., Silbert, L.J., \& Hasson, U. "Speaker-Listener Neural Coupling Underlies Successful Communication". Proceedings of the National Academy of Sciences of the United States of America (PNAS) 107, no.32, (2010), 14425-14430.

Thiel, P. Zero to One: Notes on Startups, or How to Build the Future. New York: Crown Business. 2014.

Wijayanti.T.P. "The Style of Persuasive in Home Shopping Network (HSN) of the United States". Thesis. UIN Sunan Ampel Surabaya. (2020) Accessed on June 21, 2021 from http://digilib.uinsby.ac.id/ 